\title{
Upadek Związku Radzieckiego w świetle rosyjskich podręczników do historii ${ }^{2}$
}

\begin{abstract}
The aim of the article is to point out how in contemporary Russian school history textbooks the collapse of the Soviet Union and its consequences for Russia, Europe and the whole world are shown. By combining this information with public opinion polls, aimed at analyzing Russian attitude to this controversial period in history, an attempt was made to find an answer to the question of how in the cultural memory of Russians, transmitting the experience of the older generations to the younger, this groundbreaking change in the political system operates nowadays.

The conducted analysis has shown that many Russian history textbooks present a balanced, unemotional picture of the process the collapse of the Soviet Union. However, there are also such textbooks, which include emotional negative opinions about the collapse of the Soviet superpower, considering this event as one of the most tragic moments in the history of the 20th century. The article cites excerpts from history textbooks for history, juxtaposing them with public opinion surveys (regarding the evaluation of the last CPSU Secretary Mikhail Gorbachev; an opinion about the possibility of avoiding the collapse of the USSR, the factors that cause the greatest sorrow for the state union). This juxtaposition has revealed that
\end{abstract}

${ }^{1}$ Anna Kadykało, Instytut Rosji i Europy Wschodniej, Wydział Studiów Międzynarodowych i Politycznych, Uniwersytet Jagielloński, Polska, kadykalo.anna@gmail.com.

${ }^{2}$ Stypendysta wsparty finansowaniem Fundacji na rzecz Nauki Polskiej (FNP). 
despite the passage of time, there is lack of one, acceptable to the general public version of events that took place a quarter of a century ago. Just as Russians evaluate events focused around the collapse of the USSR and its consequences differently, so authors of textbooks offer students interpretations of groundbreaking events very diverging from each other. Therefore, the article shows that the historical education of young Russians in relation to this specific period will be the sum of the family stories, reading textbook recommended by the teacher and teacher comments. This leads to the conclusion that the collapse of the USSR is an event affecting the cultural memory of Russians, though the evaluation of this period are still evolving.

\section{Keywords:}

Gorbachev, historical memory, cultural memory, history textbooks, Russia, Russian historical education, the collapse of the USSR

\section{UPADEK ZSRR - KONTROWERSJE MIMO UPEYWU LAT}

Najnowsza historia państwa rosyjskiego, obejmująca okres od upadku ZSRR do dnia dzisiejszego, znajduje się obecnie w polu szczególnego zainteresowania najwyższych władz Rosji. Widać to chociażby na przykładzie krytyki bogatej oferty szkolnych podręczników do historii najnowszej - ich różnorodność i rozpiętość tematyczna sprawiają, że uczniowie mogą zapoznać się w szkole z rozmaitymi interpretacjami wydarzeń z ostatniego dwudziestopięciolecia, z których wiele nie do końca odpowiada interesom rosyjskich władz (Карпюк, 2013).

Jednym z takich kontrowersyjnych wydarzeń bez wątpienia pozostaje upadek Związku Radzieckiego - do dziś różne są opinie zarówno na temat przyczyn, które doprowadziły do całego szeregu wydarzeń (zakończonych 25 grudnia 1991 roku złożeniem urzędu prezydenta ZSRR przez Michaiła Gorbaczowa), jak i na temat ich skutków dla republik radzieckich i zewnętrznego otoczenia.

Celem artykułu jest ukazanie, w jaki sposób we współczesnych rosyjskich podręcznikach szkolnych do historii przedstawiany jest rozpad Związku Radzieckiego; jak ocenia się ten proces, jego konsekwencje dla Rosji, Europy i świata. Poprzez zestawienie tych informacji z badaniami opinii publicznej, prowadzonymi na przestrzeni lat, ukierunkowanymi na analizę stosunku Rosjan do tego kontrowersyjnego okresu w historii, będzie poszukiwana odpowiedź na pytanie o miejsce i rolę w pamięci kulturowej Rosjan zmiany ustrojowej zainicjowanej ponad 20 lat temu. 
Należy podkreślić, że pamięć kulturowa to rodzaj pamięci zbiorowej, utrwalanej przy pomocy nośników materialnych lub rytualnych. Jej zadaniem jest międzypokoleniowy przekaz wiedzy i doświadczeń. W odniesieniu do postawionego problemu warto zdefiniować także inny rodzaj pamięci - pamięć historyczną. Jak podkreślił Mariusz Menz, pamięć ta stanowi „,szczególny rodzaj pamięci kulturowej, który odnosi się do pamięci przeszłości danej grupy społecznej (najczęściej narodu). Jest rekonstruowana w ramach odniesień właściwych w świetle potrzeb określonej teraźniejszości przez historiografię, którą ta grupa uznaje i honoruje” (Menz, 2014, s. 328). Ten rodzaj pamięci bywa traktowany jako synonim pamięci zbiorowej, społecznej i kulturowej. W warunkach rosyjskich pamięć historyczna jest ściśle zespolona z polityką państwa, żywo zainteresowanego kształtowaniem pożądanego obrazu przeszłości w świadomości społecznej. Jak podkreślili Joanna Kalicka i Piotr Witek, „wizja przeszłości oraz świadomość historyczna stanowiły od wieków przedmiot zainteresowania zarówno władzy świeckiej, jak i duchownej oraz rozmaitych grup społecznych i narodowych” (Kalicka, Witek, 2014, s. 378). Niektórzy badacze (Dorota Malczewska-Pawelec i Tomasz Pawelec) uważają, że politykę państwową w zakresie modelowania masowych wyobrażeń historycznych należałoby raczej określać terminem „polityka pamięci historycznej”, a nie „polityka historyczna”. Taki pogląd wynika z faktu, iż opisywany aspekt polityki ukierunkowany jest nie tyle na rekonstrukcję przeszłości historycznej, co na utrwalenie jej w pamięci zbiorowej społeczeństwa (Гордеев, 2014, s. 129).

\section{UPADEK ZSRR W OCZACH ROSYJSKIEGO SPOLECZEŃSTWA}

Badania socjologiczne pokazują, że w ostatnich latach wśród Rosjan wzrasta zainteresowanie historią (było nią zainteresowanych 62\% ankietowanych). Zazwyczaj do tego grona należą osoby z wyższym wykształceniem oraz mieszkańcy średniej wielkości miast. Aż 60\% Rosjan uważa, że ocena wydarzeń historycznych powinna być jedna i niezmienna, za niedopuszczalną uznając ich rewizję. Dwie trzecie ankietowanych postrzega historię jako naukę i narzędzie poznania, a co czwarty jest zdania, że w zasadzie historia nie może istnieć poza polityką i walką polityczną (ВЦИОМ: Бои за историю, 2009)3․

${ }^{3}$ Ankieta została przeprowadzona przez Wszechrosyjskie Centrum Badania Opinii Publicznej (ВЦИОМ) 3-4 października 2009 roku na grupie 1600 osób ze 140 zamieszkałych punktów w 42 obwodach, krajach i republikach Rosji. Błąd statystyczny nie przekracza 3,4\%. 
W kontekście przywołanych wyników badań nie może dziwić fakt, że tak brzemienne w skutki wydarzenie jak upadek ZSRR do dziś polaryzuje rosyjskie społeczeństwo, nadal niosąc ze sobą wiele kontrowersji i sprzecznych ocen. Jednocześnie warto podkreślić, iż wraz z upływem czasu zmienia się stosunek Rosjan do wydarzeń sprzed ćwierćwiecza. Dla naświetlenia stosunku rosyjskiego społeczeństwa do rozpadu ZSRR bardzo pomocne są badania socjologiczne przeprowadzone przez Centrum Lewady. Na pytanie zadane w 2010 roku: „Jak obecnie ogólnie odnosi się Pan/Pani do M. Gorbaczowa?” udzielono następujących odpowiedzi (Как Вы сейчас в целом относитесь к М. Горбачеву?, 2010) ${ }^{4}$ :

\begin{tabular}{ll}
\hline obojętnie & $\mathbf{4 7 \%}$ \\
\hline z rozdrażnieniem & $10 \%$ \\
\hline z niechęcią & $13 \%$ \\
\hline z pogardą & $3 \%$ \\
\hline ze wstrętem, nienawiścią & $3 \%$ \\
\hline z szacunkiem & $8 \%$ \\
\hline z sympatią & $6 \%$ \\
\hline z uznaniem & $2 \%$ \\
\hline z zachwytem & $1 \%$ \\
\hline trudno powiedzieć & $7 \%$ \\
\hline
\end{tabular}

Warto zwrócić uwagę na obojętny stosunek do Gorbaczowa niemal połowy ankietowanych oraz stosunkowo duży odsetek respondentów, którym ostatni sekretarz Komunistycznej Partii Związku Radzieckiego kojarzy się zdecydowanie negatywnie. Należy podkreślić, że odpowiedzi na identyczne pytanie, zadane w 2005 roku, były bardzo podobne do tych z 2010 roku, co wskazuje na wykrystalizowanie się stosunku Rosjan do ostatniego sekretarza KPZR.

Interesująco przedstawiają się również wyniki badania przeprowadzonego w 2012 roku, podczas którego zapytano Rosjan, czy uważają upadek ZSRR za proces, którego nie dało się uniknąć. Odpowiedzi przedstawiały się następująco (Как Вы считаете, распад Советского Союза был неизбежен - или его можно было избежать?, 2012):

4 Tę ankietę, podobnie jak pozostałe przywołane w dalszej części artykułu, przeprowadzono na grupie 1600 osób. 


\begin{tabular}{lll}
\hline & $\mathbf{1 9 9 8}$ & $\mathbf{2 0 1 2}$ \\
\hline Rozpad ZSRR był nie do uniknięcia & $24 \%$ & $31 \%$ \\
\hline Rozpadu ZSRR można było uniknąć & $58 \%$ & $48 \%$ \\
\hline Trudno powiedzieć & $18 \%$ & $21 \%$ \\
\hline
\end{tabular}

Zmiana w proporcjach odpowiedzi pomiędzy latami 1998 i 2012 dowodzi, że wraz z upływem czasu Rosjanie coraz częściej dochodzą do przekonania, iż Związek Radziecki nie miał przed sobą przyszłości, próby jego zreformowania nie byłyby udane, w związku z czym musiał się rozpaść. Zwiększający się dystans do przeszłości zmniejsza nostalgię za nią, o czym przekonują wyniki badania, podczas którego zapytano ankietowanych, czy żałują obecnie rozpadu ZSRR (Сожалеете ли Вы сейчас о распаде Советского Союза в 1991 году?, 2012):

\begin{tabular}{llll}
\hline & $\mathbf{2 0 0 0}$ & $\mathbf{2 0 0 2}$ & $\mathbf{2 0 1 2}$ \\
\hline Tak & $75 \%$ & $66 \%$ & $49 \%$ \\
\hline Nie & $19 \%$ & $23 \%$ & $36 \%$ \\
\hline Trudno powiedzieć & $6 \%$ & $11 \%$ & $15 \%$ \\
\hline
\end{tabular}

Z kolei badanie opinii publicznej przeprowadzone w 2012 roku pozwoliło wyszczególnić przyczyny żalu za upadłym państwem radzieckim. Na wspomniany żal wpłynęły następujące czynniki (В связи с чем Вы прежде всего сожалеете о распаде СССР?, 2012):

\begin{tabular}{ll}
\hline utrata poczucia przynależności do wielkiego mocarstwa & $\mathbf{5 1 \%}$ \\
\hline zniszczenie jednolitego systemu gospodarczego & $49 \%$ \\
\hline wzrost wzajemnej nieufności & $39 \%$ \\
\hline zanikanie kontaktów z krewnymi i przyjaciółmi & $26 \%$ \\
\hline trudności w swobodnym podróżowaniu & $19 \%$ \\
\hline utrata poczucia, że wszędzie można czuć się, jak w domu & $18 \%$ \\
\hline trudno powiedzieć & $1 \%$ \\
\hline
\end{tabular}

Tęsknota za silnym mocarstwem jest zauważalna zarówno wśród starszych pokoleń Rosjan, jak i wśród rosyjskiej młodzieży: „Zapotrzebowanie na silne, potężne państwo, jakim był Związek Radziecki - to także echa mitologizowanej świadomości poprzednich pokoleń” (Касамара, Сорокина, 2014, s. 62) ${ }^{5}$. Z przywołanych powyżej odpowiedzi wynika, że na poglądy Rosjan w kwestii wyda-

5 Tłumaczenie - tu i dalej - A.K. 
rzeń z 1991 roku wpłynęły zarówno czynniki ogólnopaństwowe (bycie częścią mocarstwa, posiadanie jednolitej gospodarki), jak i osobiste, prywatne (kontakty z krewnymi, brak poczucia obcości).

Jak zauważyły Walerija Kasamara i Anna Sorokina, obecnie w rosyjskiej świadomości społecznej można wyodrębnić dwie tendencje: pierwsza to pesymistyczna ocena najbliższej przyszłości Rosji i negatywna ocena teraźniejszości; natomiast druga - to nostalgia za radziecką przeszłością i idealizacja życia społeczno-politycznego w ZSRR. Mimo że stopniowo zmniejsza się odsetek Rosjan żałujących rozpadu ZSRR, to nadal dla relatywnej większości rosyjskiego społeczeństwa ideał modelu społecznego znajduje się w przeszłości. Należy podkreślić, że ta tendencja jest aktualna również w odniesieniu do młodego pokolenia, które przyszło na świat już po rozpadzie ZSRR. Stanowi to poważną przeszkodę dla wielowektorowej modernizacji kraju (Касамара, Сорокина, 2014, s. 53-54).

\section{ROSYJSKIE PODRĘCZNIKI DO HISTORII - POMOCE DYDAKTYCZNE CZY NARZĘDZIE PROPAGANDY?}

O ile starsze pokolenia Rosjan pamiętają upadek ZSRR oraz związane z nim zawirowania historyczne z własnych doświadczeń, o tyle dorastające pokolenia zapoznają się z tym okresem z opowieści rodziców i dziadków, ale przede wszystkim - z podręczników do historii. W niniejszym artykule dokonano analizy 12 podręczników do historii Rosji, przeznaczonych dla klas 11. (z podstawowym i rozszerzonym profilem nauczania historii) szkół średnich ogólnokształcących. Analizowane podręczniki zostały opublikowane w latach 2002-2014. Ponadto uwaga została skupiona na głośnej i kontrowersyjnej pomocy metodycznej (tzw. książce dla nauczyciela) autorstwa Aleksandra Filippowa ${ }^{6}$. Przeprowadzona analiza podręczników wykazała, że zawierają one podobne opisy wydarzeń poprzedzających rozpad Związku Radzieckiego: kryzysu politycznego i gospodarczego, zamachu stanu (puczu Janajewa), uzyskania autonomii przez państwa związkowe, referendum na Ukrainie dotyczącego ogłoszenia przez tę republikę niepodległości,

${ }^{6}$ Zob. Spis literatury. W publikacjach naukowych, prasie i na portalach internetowych ta pomoc metodyczna opisywana była jako „skandalicznie głośna” (Минобрнауки допустило скандальный учебник по истории России на обкатку в регионы, 2007), „poddana masowej krytyce” (Шаталин, 2007), „,będąca w epicentrum ożywionych dyskusji” (Елков, 2007), której publikacja podobna była do „eksplodującej bomby” i od razu została zaliczona przez liberalne środki masowego przekazu do grona „skandalicznych”: „Nazwa «skandaliczny podręcznik» stała się jego określeniem identyfikacyjnym” (Багдасарян, Абдулаев, Клычников і in.], 2009, s. 7. 
postępującego procesu decentralizacji ZSRR, zakończonego przez Borysa Jelcyna, Leonida Krawczuka i Stanisława Szuszkiewicza 8 grudnia 1991 roku w Puszczy Białowieskiej, podpisaniem oświadczenia o rozwiązaniu ZSRR, powołania Wspólnoty Niepodległych Państw, usankcjonowania rozpadu ZSRR przez organy władzy tego państwa. Choć „szkielet” narracji poświęconej upadkowi ZSRR jest bardzo podobny, to podręczniki różnią się w ocenie przedstawionych wydarzeń, nieraz prezentując bardzo emocjonalne opisy negatywnych skutków tego przełomowego dla świata wydarzenia. Zadaniem autora niniejszego tekstu było pokazanie, na jakich wątkach tematycznych koncentrują się autorzy podręczników (poza tradycyjnym „szkieletem” narracji o rozpadzie ZSRR). Zaznaczyć przy tym należy, że nierzadkie podobieństwo w poruszanych wątkach i rozkładaniu akcentów w dużej mierze wynika z tego, iż w zespołach redakcyjnych podręczników znajdowali się ci sami historycy.

Możliwość docierania z przekazem do szerokiego grona młodych odbiorców sprawia, że podręczniki do nauki historii znajdują się w centrum zainteresowania rosyjskich władz. W 2005 roku zgodnie z rozporządzeniem rosyjskiego Ministerstwa Edukacji i Nauki zatwierdzono „Uchwałę o trybie przeprowadzania ekspertyzy podręczników”. Taką ekspertyzę, przeprowadzoną przez Rosyjską Akademię Edukacji, pomyślnie przeszło w 2007 roku 77\% podręczników (Гордеeв, 2014, s. 133). Warto wspomnieć, że wśród zaakceptowanych książek znalazł się „,skandaliczny"7 podręcznik do najnowszej historii Rosji dla 11. klasy Historia Rosji 1945-2007 (История России 1945-2007) pod redakcją Aleksandra Filippowa. Książka miała być wysłana do kilku regionów, a po roku uzyskać szansę na dostanie się na listę zalecanych podręczników, co pozwoliłoby jej trafić do wszystkich szkół ogólnokształcących. W założeniu podręcznik miał ukształtować absolwentów szkół na prawdziwych „patriotów, nosicieli wartości społeczeństwa obywatelskiego, świadomych swojego współudziału w losach Rosji” (Минобрнауки допустило..., 2007). Podręcznik powstał na podstawie Ksiq̨żki dla nauczyciela (Филиппов, 2007) do historii najnowszej autorstwa Filippowa. Szczególnie kontrowersyjny jest jej rozdział podejmujący próbę rehabilitacji i usprawiedliwienia stalinizmu (jako jedną z przyczyn represji wskazano konieczność zapewnienia maksymalnej wydajności aparatu zarządzającego). Podręcznik zawiera wiele ocen o wydźwięku politycznym, apoteozujących okres rządów Władimira Putina. Tymczasem

7 Wspomniany podręcznik został określony mianem „skandalicznego” przez autorów szeregu publikacji, np. Минобрнауки допустило..., 2007; Скандальный школьный учебник по истории создаст новую систему образования, - Фурсенко, 2007; «Учебник Филиппова»: продолжение последовало, 2009. 
dyskusyjną pozostaje kwestia, czy ze względu na obiektywne podejście do opisywanych zdarzeń ostatnie lata powinny być w ogóle obiektem nauki w szkołach (Минобрнауки допустило..., 2007).

Podczas spotkania prezydenta Putina z historykami w 2003 roku w Rosyjskiej Bibliotece Państwowej rozmawiano m.in. na temat szkolnej edukacji historycznej i konieczności jej ścisłego powiązania z kształtowaniem tożsamości i lojalności wobec państwa. Aleksiej Iljin zaznaczył, że politycy zawsze zgadzali się, iż w uczniu należy kształtować dumę ze swojego kraju i miłość do niego. Jeśli jednak dawniej za główne zadanie historii uważano wychowanie dobrego żołnierza, to dziś - dobrego obywatela. Często podkreślanym stwierdzeniem jest to, że w szkole naucza się dzieci tego, co sami historycy określają jako narodowy mit (Ильин, 2002). Jak zauważył Gieorgij Kasjanow z Instytutu Historii Ukrainy w Narodowej Akademii Nauk Ukrainy, centralne władze państwowe Rosji coraz intensywniej dążą do skonstruowania i zaszczepienia w świadomości masowej konstytuującego mitu historycznego. Obiektami polityki historycznej są te wydarzenia z przeszłości, które budzą w społeczeństwie niezgodę i dyskusje. W tym kontekście cel polityki historycznej można sformułować jako wpojenie w świadomość społeczną pewnej dominującej wersji przeszłości. Z kolei posługiwanie się tezą o „braku patriotyzmu” w szkolnych podręcznikach do historii prowadzi do konieczności rewizji ich treści oraz jej unifikacji celem wpajania wartości patriotycznych (Касьянов, 2010). Zdarza się, że podręczniki zawierają odpowiadające władzom ideologiczne warianty interpretacji przeszłości, co służy realizacji ich interesów politycznych. Jak stwierdził Jerzy Gordziejew: „Oficjalna polityka historyczna w Rosji to dynamicznie rozwijające się, posiadające skomplikowaną strukturę zjawisko, które stanowi próbę politycznego zmonopolizowania przeszłości historycznej poprzez kształtowanie oficjalnie ustalanego obrazu przeszłości i państwową interwencję w narrację historyczną” (Гордеев, 2014, s. 163). W podobnym tonie wypowiedziała się Natalia Potapova, zauważając, że zasadnicza uwaga rosyjskiego rządu została nakierowana na przedstawianie w podręcznikach bieżącej polityki i okresu poradzieckiego (Potapova, 2015, s. 49).

W odniesieniu do wydarzeń sprzed 25 lat historycy zapytani przez portal dw.com ${ }^{8}$ stwierdzili, że podręczniki w dostatecznym stopniu naświetlają temat rozpadu ZSRR. Osobną kwestię, stanowiącą przedmiot sporów, stanowi treść przedstawianego materiału (Виноградов, 2013). Liczba podręczników do historii

8 dw.com - to niemiecki portal informacyjny „Deutsche Welle”, którego treść dostępna jest w Internecie w 30 językach świata, w tym po polsku. Ponadto stacja nadawcza „Deutsche Welle” nadaje programy radiowe i telewizyjne (od 1953 roku). 
najnowszej, w których można znaleźć opis tego procesu, wynosi około 15. Do najbardziej popularnych, tj. najczęściej wybieranych przez szkoły, należą te autorstwa Aleksandra Czubariana (Чубарьян, 2011), Aleksandra Daniłowa (Данилов, Уткин, Филиппов, 2009), Władimira Szestakowa (Шестаков, 2012), Władlena Izmozika (Измозик, Рудник, 2013) i Andrieja Lewandowskiego (Левандовский, Щетинов, Мироненко, 2013). Zazwyczaj tematowi rozpadu Związku Radzieckiego w podręczniku poświęca się 4-5 stron; przeciętnie podręcznik liczy około 350 stron, z czego wynika, że temat ten nie należy do najbardziej popularnych (Виноградов, 2013). Podręczniki koncentrujące się na przedstawieniu dziejów powszechnych, ze szczególnym zwróceniem uwagi na wydarzenia w Rosji, siłą rzeczy jeszcze bardziej skrótowo traktują analizowany temat (np. Волобуев i in., 2013). Sekretarz naukowy Instytutu Rosyjskiej Historii w Rosyjskiej Akademii Nauk i autor szeregu podręczników do historii Władimir Szestakow przyznał, że informacje na temat wydarzeń z 1991 roku są przedstawione w dosyć skąpej formie. Zdaniem uczonego, istnieje obiektywna przyczyna takiego stanu rzeczy, a mianowicie brak „fundamentalnych badań i poważnych źródeł”. Należy jednak pamiętać - kontynuuje Szestakow - iż podręczniki nie są publikacjami specjalistycznymi, dlatego wytłumaczalne jest niepoświęcenie danym etapom rozwoju historycznego tyle miejsca, ile chcieliby specjaliści. Z kolei przewodniczący rady redakcyjnej czasopisma „Nauczanie Historii w Szkole” („Преподавание истории в школе”), autor podręczników do historii Aleksandr Morozow twierdzi, że temat rozpadu ZSRR we wszystkich podręcznikach zatwierdzonych przez Ministerstwo Edukacji i Nauki został przedstawiony raczej całościowo. Zdaniem historyka, ocena wydarzeń z 1991 roku jest dość wyważona, a za najważniejsze Morozow uznał brak jednoznacznych interpretacji w podręcznikach. Natomiast redaktor naczelny czasopisma „Nauczanie Historii w Szkole” Enwer Abdułajew stwierdził, iż temat rozpadu ZSRR został zaprezentowany w podręcznikach „absolutnie niecałościowo i nieobiektywnie”. Jako błąd wskazał wyłączenie wersji o celowym rozpadzie ZSRR. Poważne zastrzeżenia względem jakości szkolnych podręczników do historii, a w szczególności tego, w jaki sposób ukazywany jest proces rozpadu ZSRR, podnosi rektor Moskiewskiego Państwowego Instytutu Stosunków Międzynarodowych (МГИМО), zastępca przewodniczącego Rosyjskiego Towarzystwa Historycznego Anatolij Torkunow. Przyznał on, że trudno oceniać niedawne wydarzenia, jednak jego zdaniem nie ma obecnie (2013 rok) żadnego podręcznika, który w pełni by go satysfakcjonował. Brak podręczników należytej jakości rektor prestiżowej uczelni uznał za główny powód niskiego poziomu wiedzy o historii ojczystej wśród absolwentów szkół średnich. Z kolei Aleksandr Morozow uważa, iż przyczyna słabego rozumienia przez uczniów 
wydarzeń historii najnowszej związana jest nie z podręcznikami, ale z systemem nauczania. Podręcznik wykorzystywany jest bowiem jedynie jako podstawa, baza, a to od nauczyciela zależy, w jaki sposób poprowadzi lekcję i jak przedstawi dany temat (Виноградов, 2013).

\section{UPADEK ZSRR WEDŁUG PRZEKAZÓW ROSYJSKICH PODRĘCZNIKÓW DO HISTORII}

Aby uzmysłowić sobie treść przekazów podręcznikowych dotyczących rozpadu Związku Radzieckiego, warto skupić się na kilku zasadniczych wątkach, które są poruszane w tej narracji. Jednym z nich jest wyrażony przez autorów stosunek do prób ratowania państwa radzieckiego. Działania podejmowane przez władze radzieckie w celu utrzymania jedności ZSRR (choć w zreformowanej postaci) oceniane są jako próba ratowania społeczeństwa przed oczywistymi (według autorów podręczników) negatywnymi skutkami upadku mocarstwa. Inicjatywa powołania Związku Suwerennych Państw, mającego stanowić odnowioną federację suwerennych równoprawnych republik radzieckich, z instytucją władzy prezydenckiej, została opisana w następujący sposób:

W istocie była to ostatnia próba centrum, przeżywającego agonię pod mocnym wpływem rwących się do niepodzielnej władzy republikańskich elit rządzących, uniknięcia niekontrolowanego rozpadu ZSRR i nieuniknionych nieszczęść milionów prostych ludzi (Левандовский i in., 2013, s. 307).

Jedynej szansy zachowania Związku upatrywał Prezydent ZSRR w jak najszybszym zawarciu nowej umowy związkowej (Загладин, Петров, 2014, s. 330).

W kolejnych dwóch podręcznikach podkreśla się nie tylko nieodpowiedzialność i partykularyzm elit rządzących w poszczególnych republikach, nieświadomych nieuchronnej rewolucji w zakresie warunków socjalnych, ale i zagrożenie wynikające z chaotycznego rozpadu mocarstwa:

Realne niebezpieczeństwo niekontrolowanego rozpadu ZSRR, grożące nieprzewidywalnymi konsekwencjami, zmusiło Centrum i republiki do poszukiwania drogi do kompromisu (Шестаков, 2012, s. 337). 
Jednakże w świadomości społecznej był już ukształtowany negatywny stosunek do struktur związkowych. Te nastroje były wzmacniane także perspektywą ponownego podziału własności, a dla elit republikańskich władza nad swoim terytorium była bardziej kusząca niż zachowanie jedności związkowej (Киселев, Попов, 2012, s. 260).

Dyskusje nad utworzeniem Wspólnoty Niepodległych Państw straciły na znaczeniu, gdy Ukraina ogłosiła powstanie niezależnego państwa i nie zgodziła się na podpisanie nowej umowy związkowej. 1 grudnia 1991 roku na Ukrainie odbyło się referendum, w którym ponad 90\% wyborców opowiedziało się za powstaniem niezależnego państwa. Wybrany na prezydenta Ukrainy Leonid Krawczuk 5 grudnia 1991 roku ogłosił wyjście republiki z umowy związkowej z 1922 roku, co w dwóch podręcznikach zostało skomentowane następująco: „Rozpoczął się proces żywiołowego rozpadu ZSRR” (Загладин, Козленко, Минаков, Петров, 2007, s. 405; Загладин, Петров, 2014, s. 330).

Z kolei w podręczniku Aleksaszynej szczegółowo przeanalizowano przyczyny rozpadu Związku Radzieckiego, wyszczególniając czynniki obiektywne oraz subiektywne. Do tych pierwszych zaliczane są: ukształtowanie w republikach związkowych (przy pomocy państwa związkowego) podstaw przemysłu i rolnictwa; znaczny postęp w zakresie edukacji, nauki i kultury, jaki miał miejsce w okresie radzieckim; osłabienie oraz demontaż centrum związkowego; złagodzenie aparatu represyjnego podczas pieriestrojki, a także politykę świata zachodniego, który nie był zainteresowany utrzymaniem drugiego supermocarstwa. Natomiast wśród czynników subiektywnych wymienia się: sytuację polityczną w ZSRR, począwszy od okresu pieriestrojki; wzmocnienie walki o władzę w kierownictwie KPZR i ZSSR, a także ambicje, interesy indywidualne i grupowe liderów republik związkowych (Алексашина, Данилов, Косулина, 2010, s. 328).

W trzech podręcznikach uwaga uczniów jest także zwracana na zmiany w warstwie symbolicznej: „25 grudnia Prezydent ZSSR złożył swoje pełnomocnictwa. W tym samym dniu Rada Najwyższa Rosji zatwierdziła zamiast RSFSR nową oficjalną nazwę państwa - Federacja Rosyjska. Nad Kremlem wzniesiono trójkolorową rosyjską flagę” (Данилов, Уткин, Филиппов, 2009, s. 227); „ZSRR przestał istnieć i nad Kremlem opuszczono flagę Związku Radzieckiego” (Чубарьян, 2011, s. 220; por. Измозик, Рудник, 2013, s. 305).

Autorzy podręczników podkreślają również, że okres zapoczątkowany w grudniu 1991 roku, ze względu na swój przejściowy charakter, doczekał się różnych ocen, zarówno w literaturze naukowej, jak i publicystyce: 
Zwolennicy socjalistycznego modelu rozwoju uważają, że rozpad ZSRR i zniszczenie systemu radzieckiego to jedynie przypadkowy zygzak historii, wynik nieprofesjonalizmu, błędów i nawet zdrady polityków. A więc system radziecki zasługuje na restaurację. Dla zwolenników innych podejść zmiana wektora społecznego rozwoju kraju w ostatnim dziesięcioleciu XX w. to nie przypadek, ale uzasadnione działanie całego popaździernikowego rozwoju, szansa na kontynuację przerwanej w 1917 r. drogi do demokracji i wolności (Шестаков, 2012, s. 340-341).

Oceniający ten kontrowersyjny okres zgadzają się co do tego, że ze względu na zakres zmian może on być zestawiany z najbardziej dramatycznymi epokami rosyjskiej historii. Akcentuje się wagę czynnika społecznego, rewolucyjnych zmian, które stanowiły nieszczęście dla milionów ludzi (Левандовский i in., 2013, s. 307).

Rozpad państwa opisywany jest jako wydarzenie tragiczne: „Rozpad Związku Radzieckiego i koniec wielkiego mocarstwa stały się jednymi z najbardziej tragicznych wydarzeń historii światowej pod koniec XX wieku” (Чубарьян, 2011, s. 220-221). Podkreśla się przy tym, że do dziś historycy spierają się na temat tego, czy możliwe było utrzymanie Związku Radzieckiego, czy to w formie konfederacji, czy to w innej postaci (Чубарьян, 2011, s. 221). Warto podkreślić, iż autorzy niemal wszystkich przeanalizowanych podręczników (11 na 12) opracowali szereg zadań dla uczniów, najczęściej zachęcając ich do rozważenia i przeanalizowania wspomnianej powyżej kwestii, która, jak pokazano, nadal stanowi przedmiot sporu zarówno w rosyjskim społeczeństwie, jak i w społeczności naukowej. Jedno z zadań, jakie postawiono przed uczniami, zostało sformułowane następująco: „Rozpad ZSRR: zjawisko uzasadnione czy wynik zbiegu okoliczności?” (Левандовский i in., 2013, s. 304; Данилов і in., 2009, s. 228; Волобуев і in., 2013, s. 268). W innym podręczniku uczniowie mieli się zastanowić nad tym, czy upadek systemu radzieckiego był nie do uniknięcia (Измозик, Рудник, 2013, s. 305). W kolejnych podręcznikach zachęcono uczniów do przeanalizowania przyczyn rozpadu ZSRR (Дмитренко i in., 2002, s. 535), a także do przeprowadzenia ankiety w swoim najbliższym otoczeniu, badającej stosunek respondentów do rozpadu ZSRR, oraz do analizy otrzymanych wyników (Левандовский i in., 2013, s. 308). Swój stosunek do wydarzeń z 1991 roku młodzi Rosjanie mogli również wyrazić, wypełniając zadanie polegające na przeanalizowaniu fragmentów wypowiedzi Gorbaczowa i Jelcyna na temat układu białowieskiego i wyborze bardziej przekonujących argumentów (Волобуев, Кулешов, 2009, s. 266-267). 
Dwa podręczniki akcentują międzynarodowe konsekwencje upadku ZSRR, pokazując negatywny wpływ tego wydarzenia na układ sił na świecie poprzez dokonanie fundamentalnej transformacji struktury ładu międzynarodowego: „Upadek Związku Radzieckiego wprowadził USA do kategorii jedynego supermocarstwa świata. W grudniu 1991 roku amerykański prezydent G. Bush pogratulował swojemu narodowi zwycięstwa w «zimnej wojnie»” (Левандовский i in., 2013, s. 317; Измозик, Рудник, 2013, s. 310). Jak zaznaczono w podręczniku Izmozika i Rudnika, analitycy pozytywnie oceniający rozpad ZSRR akcentują fakt, że wraz z zakończeniem „zimnej wojny” Związek Radziecki mógł stać się pełnoprawnym członkiem społeczności międzynarodowej, zrezygnować z niezwykle kosztownego wyścigu zbrojeń i skierować uwagę na problemy gospodarki wewnętrznej. Z kolei ich oponenci podkreślają, iż już od końca lat 80. rząd radziecki nazbyt ustępował Zachodowi, a w szczególności USA, nie uzyskując nic w zamian. To natomiast doprowadziło do utraty przez ZSRR parytetu wojskowo-strategicznego z USA oraz statusu wielkiego mocarstwa (Измозик, Рудник, 2013, s. 310).

Z kolei w książce dla nauczyciela pod redakcją Filippowa przytaczana jest ocena konsekwencji rozpadu ZSRR autorstwa prezydenta Rosji Władimira Putina, która ze względu na dużą popularność przywódcy w społeczeństwie może wywierać wpływ na światopogląd uczniów, zapoznanych z nią podczas lekcji historii:

Według mojego głębokiego przekonania rozpad Związku Radzieckiego to ogólnonarodowa tragedia na ogromną skalę. Myślę, że szeregowi obywatele byłego Związku Radzieckiego i obywatele przestrzeni poradzieckiej, krajów WNP, szeregowi obywatele, nic na tym nie zyskali. Ale to się dokonało. Zostało to przyjęte przez narody tych krajów, uznane przez wspólnotę międzynarodową i samą FR. To pełnoprawne niezależne państwa i należy odnosić się do nich z szacunkiem. Z szacunkiem - to znaczy uznawać ich prawowite interesy i oto właśnie na tym gruncie są tu i plusy także dla nas. Plusy polegają na tym, że Rosja powinna przestać być dojną krową dla wszystkich i dla każdego (Филиппов, 2008, s. 333).

\section{STOSUNEK ROSJAN DO OSTATNIEGO SEKRETARZA KPZR}

Osobną kwestię, również poruszaną w podręcznikach, stanowi ocena roli ostatniego sekretarza KPZR - Michaiła Gorbaczowa - w procesie rozpadu Związku Radzieckiego. Gorbaczow, laureat Pokojowej Nagrody Nobla z 1990 roku, jest diametralnie różnie oceniany w ojczyźnie i poza jej granicami. W 2004 roku fun- 
dacja „Opinia społeczna” („Общественное мнение”) przeprowadziła badania koncentrujące się na postrzeganiu Gorbaczowa przez rosyjskie społeczeństwo. Na pytanie: „Na Zachodzie wielu uważa M.S. Gorbaczowa za wybitnego działacza politycznego XX w. A czy Pan/Pani osobiście podziela takie zdanie o M.S. Gorbaczowie?” respondenci udzielili następujących odpowiedzi (Филиппов, 2008, s. 372):

\begin{tabular}{llll}
\hline & $\mathbf{1 9 9 5}$ & $\mathbf{2 0 0 1}$ & $\mathbf{2 0 0 4}$ \\
\hline Tak & $20 \%$ & $27 \%$ & $24 \%$ \\
\hline Nie & $69 \%$ & $62 \%$ & $63 \%$ \\
\hline Trudno powiedzieć & $11 \%$ & $12 \%$ & $13 \%$ \\
\hline
\end{tabular}

Natomiast na pytanie: „Jak Pan/Pani uważa, czy ogólnie M.S. Gorbaczow przyniósł naszemu narodowi więcej pożytku, czy szkody?” odpowiedzi rozłożyły się następująco (Филиппов, 2008, s. 372):

\begin{tabular}{lll}
\hline & $\mathbf{2 0 0 1}$ & $\mathbf{2 0 0 4}$ \\
\hline Więcej pożytku & $14 \%$ & $11 \%$ \\
\hline W równej mierze i pożytek, i szkodę & $21 \%$ & $21 \%$ \\
\hline Więcej szkody & $56 \%$ & $53 \%$ \\
\hline Trudno powiedzieć & $9 \%$ & $15 \%$ \\
\hline
\end{tabular}

Rezultaty badań przekonują, że stosunek rosyjskiego społeczeństwa wobec Gorbaczowa nie ulega na przestrzeni lat wyraźnym wahaniom - w większości Rosjanie nadal negatywnie oceniają ostatniego sekretarza KPZR. W przeciwieństwie bowiem do społeczeństw zachodnich, traktujących Gorbaczowa jak bohatera, który przyczynił się do upadku radzieckiego imperium, zagrażającego światowemu pokojowi, społeczeństwo rosyjskie postrzega jego rolę lokalnie, a nie globalnie, wiążąc jego nazwisko z utratą stabilności, pewności jutra i gwarancji socjalnych.

W analizowanej książce dla nauczyciela - w podrozdziale „Informacja do przemyślenia” znalazła się ocena historycznej roli Gorbaczowa, z którego nazwiskiem związane są tak ważne dla sytuacji międzynarodowej wydarzenia, jak: zakończenie „zimnej wojny”, demokratyzacja ZSRR i Europy Wschodniej, początek przejścia do gospodarki rynkowej i rozpad ZSRR. Choć, jak wskazano, nikt nie żałuje zakończenia globalnej konfrontacji i stałego balansowania na granicy wojny jądrowej, to mało kto w Rosji cieszy się z rozpadu ZSRR. Wiąże się to z faktem przekształcenia dotychczas swoich, rodzimych miast (np. Kijowa i Tallina) w stolice zagranicznych państw (Филиппов, 2008, s. 365-366). 
Oceniając Gorbaczowa, warto odpowiedzieć na pytanie, czy pieriestrojka była nieunikniona. Zdaniem autorów opracowania metodycznego - nie, co z humorem skomentował sam były I sekretarz w dniu swoich 75 . urodzin, odpowiadając na pytanie, kim byłby dziś, gdyby nie pieriestrojka: „Generalnym sekretarzem KC KPZR. Zdrowie jeszcze jest, a trwałości systemu na mój wiek jeszcze by wystarczyło”. Jak podkreślają autorzy opracowania, reżim radziecki był zabezpieczony przed atakiem z zewnątrz przez broń jądrową, a przed oddolną rewolucją - przez przenikający wszystkie warstwy społeczne aparat KGB (Филиппов, 2008, s. 367). Wynika więc z tego, że ani opóźnienie technologiczne w porównaniu z Zachodem, ani problemy gospodarcze nie mogły doprowadzić do zmiany systemu. Impuls w kierunku zmian musiał zatem wyjść ze strony samych władz:

A ponieważ żadnego bezpośredniego zagrożenia dla władzy nie było, to musiały to być działania motywowane wysoką ideą. Ta ideowa motywacja do demokratycznego przekształcenia radzieckiego ustroju mogła wypływać jedynie z samej radzieckiej ideologii. Naturalną i jedyną formą takiej motywacji było dążenie do oczyszczenia ideologii od późniejszych nawarstwień, jej ożywienie poprzez zwrócenie się do Marksa i Lenina i ich „nowego odczytania” w duchu demokratycznym i liberalnym [...]. Tylko to, że Gorbaczow, kiedy mówił „więcej socjalizmu” i ,jak uczył Lenin”, szczerze w to wierzył, mogło dać mu siły do rozpoczęcia pieriestrojki (Филиппов, 2008, s. 368).

W opracowaniu podkreślono jednakże, że Gorbaczow-reformator nie był najlepszym gwarantem rozwoju - dużo bardziej taki człowiek przydałby się wcześniej, w latach 60., kiedy powszechna była wiara w możliwość odnowienia ustroju radzieckiego (Филиппов, 2008, s. 369). To dlatego rozpad ZSRR można uznać za dowód braku możliwości demokratycznego odnowienia „realnego socjalizmu”, choć wraz z upływem czasu ten punkt widzenia stracił swą moc ze względu na przykłady takich państw jak Chiny czy Wietnam. W opracowaniu wskazano, że analizując działania Gorbaczowa i zestawiając je z chińskim doświadczeniem, wielu badaczy (przede wszystkim amerykańskich, np. Zbigniew Brzeziński) doszło do wniosku, iż reformy polityczne należało przeprowadzać dopiero wtedy, gdy reformy gospodarcze podniosłyby poziom życia. Prowadzi to do konkluzji, że rozpad ZSRR nie musiał stać się faktem, jednak zbieg okoliczności (spadek cen ropy w momencie rozpoczęcia reform), polityka prowadzona przez poszczególnych działaczy, błędy reformatorów doprowadziły do upadku państwa. Akcentuje się jednak fakt, iż Rosjanie, wbrew amerykańskiej opinii, nie przegrali „zimnej wojny”, a wybór demokracji i gospodarki rynkowej był samodzielnym 
wyborem narodu radzieckiego (Филиппов, 2008, s. 370-371): „Główną zasługą M.S. Gorbaczowa była głęboka demokratyzacja kraju. To właśnie on zniósł cenzurę, wprowadził konkurencyjne wybory, uczynił realnymi istniejące wcześniej jedynie na papierze prawa i wolności obywateli. Nie będzie przesadą powiedzenie, że M.S. Gorbaczow dał radzieckiemu narodowi wolność. Cena okazała się być wielka” (Филиппов, 2008, s. 371).

\section{PODSUMOWANIE}

Należy podkreślić, że zdecydowana większość przeanalizowanych rosyjskich podręczników do historii przedstawia wyważony, pozbawiony emocji obraz procesu rozpadu Związku Radzieckiego. Nie brak jednak i takich podręczników oraz pomocy metodycznych (podręcznik Czubariana, książka dla nauczyciela Filippowa), które zawierają bardzo emocjonalne negatywne oceny upadku radzieckiego mocarstwa, uważając to wydarzenie za jeden z największych błędów i jeden z najbardziej tragicznych momentów historii XX wieku. Różnorodność istniejących interpretacji przedstawionego zjawiska wynika z szeregu czynników: część autorów ulega wpływom kremlowskich inspiracji, inni podporządkowują się poprawności politycznej, oczekiwaniom odbiorców, strategiom wydawniczym i wreszcie - własnym sympatiom politycznym i światopoglądowi (Берелович, 2002). Na podstawie przywołanych w artykule fragmentów podręczników do historii, zestawionych z badaniami opinii społecznej, można stwierdzić, że mimo upływu lat ciągle brak jednej, wykrystalizowanej, możliwej do zaakceptowania przez ogół społeczeństwa wersji wydarzeń sprzed ćwierćwiecza. Rosjanie różnie oceniają wydarzenia zogniskowane wokół rozpadu ZSRR i jego konsekwencje, podobnie autorzy podręczników - proponują uczniom odbiegające od siebie interpretacje przełomowych wydarzeń. Edukacja historyczna młodych Rosjan w odniesieniu do tego konkretnego okresu stanowić zatem będzie sumę opowieści rodzinnych, lektury rekomendowanego przez nauczyciela podręcznika oraz komentarzy pedagoga (częściowo wypracowanych na podstawie pomocy metodycznych). Powyższe uwagi prowadzą do wniosku, że upadek ZSRR to wydarzenie wpływające na pamięć kulturową Rosjan, choć oceny jego postrzegania ciągle ewoluują, a niemałą rolę odgrywają w tym procesie wielowektorowe działania władz, skoncentrowane wokół polityki historycznej. 


\section{Literatura:}

Rosyjskie podręczniki do nauki historii i opracowania metodyczne dla nauczycieli:

Алексашина, Л., Данилов, А., Косулина, Л. (2010). История. Россия и мир в XX-начале XXI века. 11 класс. Базовый уровень. Москва: Просвещение.

Волобуев, О., Клоков, В., Пономарев, М., Рогожкин, В. (2013). История. Россия и мир. 11 класс. Базовый уровень. Москва: Дрофа.

Волобуев, О., Кулешов, С. (2009). История России. XX-начало XXI века. 11 класс. Базовый уровень. Москва: Мнемозина.

Данилов, А., Уткин, А., Филиппов, А. (ред.). (2009). История России 1945-2008. 11 класс. Москва: Просвещение.

Дмитренко, В., Есаков, В., Шестаков, В. (2002). История Отечества. ХХ век. 11 класс. Москва: Дрофа.

Загладин, Н., Козленко, С., Минаков, С., Петров, Ю. (2007). История России. XX-начало XXI века. 11 класс. Москва: Русское слово.

Загладин, Н., Петров, Ю. (2014). История. Конец XIX-начало XXI века. 11 класс. Базовый уровень. Москва: Русское слово.

Измозик, В., Рудник, С. (2013). История России. 11 класс. Москва: Вентана-Граф.

Киселев, А., Попов, В. (2012). История России. XX-начало XXI века. 11 класс. Базовый уровень. Москва: Дрофа.

Левандовский, А., Щетинов, Ю., Мироненко, С. (2013). История России. XX-начало XXI века. 11 класс. Базовый уровень. Москва: Просвещение.

Филиппов, А. (2007). Новейшая история России 1945-2006 гг.: Книга для учителя. Москва: Просвещение.

Филиппов, А. (ред.). (2008). История России. 1945-2008 гг. Книга для учителя. Москва: Просвещение.

Чубарьян, А. (ред.). (2011). История России. XX-начало XXI века. 11 класс. Профильный и базовый уровни. Москва: Просвещение.

Шестаков, В. (2012). История России. XX-начало XXI века. 11 класс. Профильный уровень. Москва: Просвещение.

Pozostała literatura:

Багдасарян, В., Абдулаев Э., Клычников В. [i in.] (2009). Школьный учебник истории и государственная политика. Москва: Научный эксперт.

Берелович, В. (2002). Современные российские учебники истории: многоликая истина или очередная национальная идея?, перевод А. Маркова. Неприкосновенный запас, № 4 (24). Pobrane z: http://magazines.russ.ru/nz/2002/4/brel.html, [dostęp: 5.05.2016].

В связи с чем Вы прежде всего сожалеете о распаде СССР? (2012). Pobrane z: http://www.levada.ru/archive/pamyatnye-daty/v-svyazi-s-chem-vy-prezhde-vsegosozhaleete-o-raspade-sssr, [dostęp: 26.07.2015].

Виноградов, Е. (2013). Распад СССР в школьных учебниках: для историков мало, для учеников много. Pobrane z: http://www.dw.com/ru/распад-ссср-в-школьных- 
учебниках-для-историков-мало-для-учеников-много/а-17006987, [dostęp: 7.07. 2015].

ВЦИОМ: Бои за историю. (2009). Pobrane z: http://www.arhperspectiva.ru/news/ 35144-10540.html, [dostęp: 10.08.2015].

Гордеев, Ю. (2014). К вопросу об исторической политике в России. W: R. Król-Mazur, M. Lubina (red.), Na wschód od linii Curzona. Księga jubileuszowa dedykowana profesorowi Mieczysławowi Smoleniowi (s. 127-164). Kraków: Księgarnia Akademicka.

Елков И. (2007). Новейшая история России - что было с нами вчера. „Российская газета” - Федеральный выпуск, № 4410 (0). Pobrane z: http://rg.ru/2007/07/11/ istoriya.html, [dostęp: 5.05.2016].

Ильин, А. (2002). Зачем Путин встречался с историками? Pobrane z: http://polit.ru/ article/2003/11/28/istoriki/, [dostęp: 9.08.2015].

Как Вы сейчас в целом относитесь к М. Горбачеву? (2010). Pobrane z: http://www. levada.ru/archive/pamyatnye-daty/kak-vy-seichas-v-tselom-otnosites-k-m-gorbachevu, [dostęp: 26.07.2015].

Как Вы считаете, распад Советского Союза был неизбежен - или его можно было избежать? (2012). Pobrane z: http://www.levada.ru/archive/pamyatnye-daty/kak-vyschitaete-raspad-sovetskogo-soyuza-byl-neizbezhen-ili-ego-mozhno-bylo-, [dostęp: 26.07.2015].

Kalicka, J., Witek, P. (2014). Polityka historyczna. W: M. Saryusz-Wolska, R. Traba (red.), J. Kalicka (współpraca), Modi memorandi. Leksykon kultury pamięci (s. 378-387). Warszawa: Wydawnictwo Naukowe Scholar.

Карпюк, И. (2013). Одна на всех. Pobrane z: http://polit.ru/article/2013/04/24/history/, [dostęp: 20.07.2015].

Касамара, В., Сорокина, А. (2014). Студенческая молодежь о советском прошлом и российском настоящем. W: M. Kowalska, M. Kuryłowicz (red.), Fenomen Rosji. Pamięć przeszłości i perspektywy rozwoju. Cz. I. Pamięć o przeszłości w idei i kulturze Rosji (s. 53-63). Kraków: Księgarnia Akademicka.

Касьянов, Г. (2010). Russian Analytical Digest посвящен исторической политика в России. Русский вопрос, 1. Pobrane z: http://www.russkiivopros.com/?pag=one\&id=314\&kat=8\&csl=46, [dostęp: 9.08.2015].

Menz, M. (2014). Pamięć historyczna. W: M. Saryusz-Wolska, R. Traba (red.), J. Kalicka (współpraca), Modi memorandi. Leksykon kultury pamięci (s. 328-330). Warszawa: Wydawnictwo Naukowe Scholar.

Минобрнауки допустило скандальный учебник по истории России на обкатку в регионы. (2007). Pobrane z: http://www.newsru.com/russia/26dec2007/obrvalk. html, [dostęp: 9.08.2015].

Potapova, N. (2015). Normativity in Russian History Education: Political Patterns and National History Textbooks. Journal of Social Science Education, Vol. 14, Number 1, s. 47-55. DOI 10.2390/jsse-v14-i1-1378.

Скандальный школьный учебник по истории создаст новую систему образования, Фурсенко. (2007). Pobrane z: http://newdaynews.ru/moskow/157134.html, [dostęp: 5.05.2016].

Сожалеете ли Вы сейчас о распаде Советского Союза в 1991 году? (2012). Pobrane 
z: http://www.levada.ru/archive/pamyatnye-daty/sozhaleete-li-vy-seichas-o-raspadesovetskogo-soyuza-v-1991-godu, [dostęp: 26.07.2015].

«Учебник Филиппова»: продолжение последовало. (2009). Pobrane z: http://urokiistorii. ru/current/view/2009/10/uchebnik-filippova, [dostęp: 5.05.2016].

Шаталин В. (2007). Чему учит „История России”. Pobrane z: http://www.dw.com/ru/ чему-учит-история-россии/а-3023328, [dostęp: 7.05.2016]. 